\title{
»The Right Chorale«: Studies in Biblical Law and Interpretation
}

[»The Right Chorale«: Studien zur biblischen Rechtshermeneutik.]

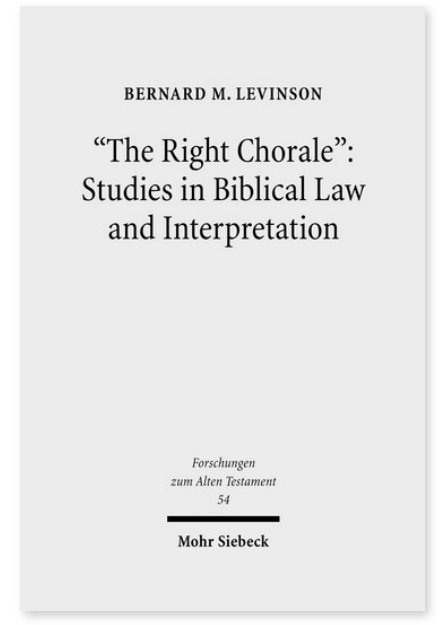

2008. XXIII, 432 Seiten (plus 34 figures). FAT 54

ISBN 978-3-16-151095-3 DOI 10.1628/978-3-16-151095-3 eBook PDF 139,00€

ISBN 978-3-16-149382-9

Leinen $139,00 €$
Veröffentlicht auf Englisch.

Der Band vereint zwölf Studien zur Komposition, Deutung, Bearbeitung und Weiterüberlieferung des alttestamentlichen Rechts. Bernard Levinson schlägt einen weiten Bogen, der sich von den literarischen Vorstufen im Keilschriftrecht bis zu der Neuinterpretation erstreckt, die das biblische Recht in der Epoche des zweiten Tempels erfahren hat. Es entsteht ein fundiertes Bild der Schriftkultur des Alten Israel. Die israelitischen Schreiber waren gebildete Leser, Denker und Schriftsteller, die sich ihrer Stellung in der Literatur- und Geistesgeschichte bewusst waren, so wie sie ihrerseits das überlieferte kulturelle Erbe sich immer von neuem angeeignet und in neue Formen gegossen haben. Die im Laufe von anderthalb Jahrzehnten entstandenen Studien sind umfassend aktualisiert und werden durch eine neue Einleitung erschlossen. Im einzelnen werden behandelt: die Verknüpfung zwischen Gesetz und Erzählung; die engen Verbindungen zwischen dem Deuteronomium und den neuassyrischen Loyalitäts-Eiden; das Verhältnis des Deuteronomiums zum Bundesbuch. Fragen der Methodologie werden erörtert und der Beitrag der Bibel zur Rechtsauffassung der westlichen Welt. Die Sammlung ist ein grundlegender Beitrag zur Entstehung des Pentateuchs und zur Geschichte des biblischen Rechts.

Inhaltsübersicht

I. Setting the Agenda: Why Biblical Law Matters

1."The Right Chorale«: From the Poetics of Biblical Narrative to the Hermeneutics of the Hebrew Bible 2.The Seductions of the Garden: The Genesis of Hermeneutics as Critique

3.The Covenant at Mount Sinai: The Argument of Revelation

4.Deuteronomy's Conception of Law as an »ldeal Type«: A Missing Chapter in the History of Constitutional Law

II. The Paradigm of Legal Hermeneutics: Close Studies and Test Cases

5.The »Effected Object« in Contractual Legal Language: The Semantics of »If You Purchase a Hebrew Slave (Exodus 21:2)

6.Textual Criticism, Assyriology, and the History of Interpretation: Deuteronomy 13:7a as a Test Case in Method

7.Recovering the Lost Original Meaning of ולא תכסה עליו (Deuteronomy 13:9)

8."But You Shall Surely Kill Him!«: The Text-Critical and Neo-Assyrian Evidence for MT Deuteronomy 13:10

III. Debate and Dialogue: The Question of Method

9.The Case for Revision and Interpolation within the Biblical Legal Corpora

10.Calum M. Carmichael's Approach to the Laws of Deuteronomy

11.The Hermeneutics of Tradition in Deuteronomy: A Reply to J. G. McConville

12.Is the Covenant Code an Exilic Composition? A Response to John Van Seters

Bernard M. Levinson is Professor of Jewish Studies and Hebrew Bible and of Law at the University of Minnesota in Minneapolis.

Jetzt bestellen:

https://mohrsiebeck.com/buch/the-right-chorale-studies-in-biblical-law-and-interpretation-9783161510953?no cache=1 order@mohrsiebeck.com

Telefon: +49 (0)7071-923-17

Telefax: $+49(0) 7071-51104$ 